\title{
Analysing Enabling Factors Affecting the On-site Productivity in Indian Construction Industry
}

\author{
Saurav Dixit ${ }^{1 *}$ \\ 1 School of Construction, Faculty of Construction Project Management, RICS School of Built Environment, Amity University, \\ Noida, India, Sector - 125, Noida 201313 (UP) India \\ * Corresponding author, e-mail: sauravarambol@gmail.com
}

Received: 18 June 2018, Accepted: 07 September 2018, Published online: 27 November 2018

\begin{abstract}
The growth in construction productivity is low and do not continue for a long span of time. The purpose of the present research paper is to analyse the factors affecting on-site construction productivity in Indian construction industry. The tools used for the analysis are reliability analysis to check the consistency of the data, Pearson correlation analysis to mathematically validate the factor analysis, and linear regression analysis to propose a framework of factors affecting construction productivity. The findings of the reliability analysis concludes that the all the factors having a value of more than 0.67 , which is considered to be good for the study, and the findings of the study conclude that the most significant 3 attributes grouped in linear regression analysis change in scope (R2), revision in drawings (R15), and response to change orders (R3) having maximum impact over the construction productivity. The research paper attempts to provide an insight and better understanding of the factors affecting on-site construction productivity in India and the ways and means to control and improve construction productivity of construction projects.

"This paper is the revised version of the paper that has been published in the proceedings of the Creative Construction Conference 2018: Dixit, S., Mandal, S. N., Thanikal, J. V, \& Saurabh, K. (2018). Critical Analysis of Factors Affecting the on-site Productivity in Indian Construction Industry, (July), 38-45. https://doi.org/10.3311/CCC2018-006"
\end{abstract}

Keywords

construction productivity, construction industry, on-site productivity, project management, Indian construction industry

\section{Introduction}

Each and every project is unique in nature and a number of factors associated with it. It is like a living entity i.e. all the living entities looks the same, but we all have unique features. So it is not easy to follow a set of instructions and complete the projects in a similar way. And the same with construction projects. The construction projects are more complex in nature as compared to the other projects. And the exposure to nature is one of the main difference in the construction project and other projects. Completion of a construction project on time and within budget is one of the main focus and key objective of a construction manager / project manager. It is however not that simple because a construction project is like a living entity and it requires interconnection and coordination of a number of stakeholders and many of them have their individual targets and goals, which sometimes create a conflict of interest between the teams and within the teams. But still the success of any project is repeatable and it is possible to find out a set of attributes for the success of a construction project and it requires a controlled discipline and hardworking.

Approximately $50 \%$ of the mega-construction projects are delayed in completion, over-budget, and experience issues of poor quality of construction. And one of the main issue for the above issues is poor or low construction productivity of the projects. Because when your projects are not performing within the scheduled productivity is tends them to go over-budget and delayed in the completion of the projects. And in a number of studies, it is observed that when a project is delayed the project management team has to compromise with the quality of the construction and even few cases they end up compromising with safety as well.

The productivity of construction projects is one of the measures for performance of the construction projects at the industry level based on its relationship with economic development. The most countries encounter the issue of low productivity as per the statistical data 
available in the public domain (OECD, 2012). The majority of the construction projects are suffering from two main issues those are a delay in completion, and cost overrun. According to (Arashpour et al., 2014; Dougherty et al., 2010; Sezer, 2015; Sezer and Bröchner, 2014) poor productivity is one of the primary reasons for it. The productivity of a construction project is affected by a number of attributes either directly or indirectly. So the loss of revenues due to the low on-site productivity of construction projects is one of the main areas of discussion for the researchers. And a number of researchers concluded that the productivity can be improved through a proper control mechanism of the attributes affecting productivity. The current research focuses on identification, analyses and grouping of the critical factors affecting on-site construction productivity in the Indian context.

Ganesan (1984) introduces a regression model that established a linking between worksite productivity to process improvement initiatives (PII). This model provides insight and helps the industry to predict the expected value of productivity at the beginning of the Project on the basis of certain inputs such as design competition, Project manager's dedication, Project vision and others. The model was created specifically from temporary worker particular data and subjected to thorough factual investigation. The model gives project supervisors as front-line industry workers to ponder and reasonable way to deal with project management and productivity improvement (Zhai et al., 2009). Through investigation of difference and regression analysis, the researchers found that activities possess changes in the material innovation have observed significant improvement in productivity and sustainable long-term growth. The research demonstrates that there is a direct linkage between changes in material innovation and partial factor productivity than in labor productivity (Grau et al., 2009a). Information technology (IT) has been utilized to expand robotization and a mix of data frameworks on a construction project for more than two decades. However, prove that general expenses have been reduced or project execution has been enhanced with IT in construction is limited. A complete comprehension of the connection amongst IT and undertaking execution enables industry workers to better comprehend the probable results of usage of IT application and moreover benefits analysts in enhancing the viability of their IT advancement efforts. The authors concluded that construction labor productivity has a positive relationship with the utilization of automation and incorporation on the selected project. Best (2010) suggested that there were many reasons looking at construction productivity between nations is a complicated task. One key issue is that of changing over construction expenses to a common currency. This issue can be overcome generally just by utilizing a basket of construction materials and labor, named a BLOC (Basket of Locally Obtained Commodities), as a unit of construction cost. Normal BLOC costs in every area are ascertained from data acquired from a number of sources (quantity surveyors, estimators). Lower BLOC counterparts speak to higher productivity as different sources of data (to great extent materials) are consistent. The technique gives a generally straightforward and coordinate strategy for comparing productivity between different locations.

\subsection{Construction Industry}

The construction industry is one of the most important and significant sectors and supports the economic development of a country. It contributes to the economy, promotes growth, provides employment to the masses, and established a linkage between the economy and other industries (Abdul Kadir et al., 2005; Mahamid, 2013). The construction sector is the engine of growth for a country and creates a flow of services and goods with other sectors (Dixit et al., 2017a). Improving construction productivity enables to save the cost of per capita and also increase the revenue of the firms. Increase in the revenues from improved CP provides an additional flow to the economy and as construction industry provides a linkage to all other industries as a part of their business process. The measures to be adopted to improve the performance of construction projects has been identified as critical and troublesome problems (Mojahed and Aghazadeh, 2008). The construction industry faced a number of issues including low rates of productivity growth and declining growth that has been entertained by a number of researchers for many years. The firms are aware of that issue and investing to know the reasons for declining the productivity (Jarkas et al., 2012). In this paper, the introduction is revised and a few more concepts of construction productivity are included to make it much more comprehensive and sound in terms of the quality of the paper.

\section{Literature review}

Productivity has been one of the most researched topics in the Indian construction industry in the last few decades. Factors affecting productivity may have a short-term or longterm effect on the project, some affect the productivity for a short duration but have a ripple effect on it. Productivity consists of various attributes like labor, finance, infrastructure, 
plant and machinery, facilities etc. Various studies in different countries have been carried out to identify the factor affecting labor productivity. Various methodologies and approaches have been adopted by researchers who have come with different schemes in the categorization of factors affecting productivity (Rivas et al., 2011).

$\mathrm{Li}$ and Liu (2011) proposed an analysis technique to measure capital productivity changes by the evaluation of factors influencing productivity levels in the construction industry. And applied it in the Australian construction industry. The research discoveries are relied upon to be useful for settling on strategy and key choices to enhance the capital productivity execution.

U. S. Department of Labor (Sveikauskas et al., 2014) suggests that measuring productivity improvement in construction has been a difficult task, generally in light of the fact that dependable output deflators are rare. This paper highlights the report of a Bureau of Labor Statistics explores gather assembled to gauge construction productivity improvement (Kannan, 2011). This paper relates a portion of the current academic research to industry rehearses. In doing as such, it approves a few sections of the exploration and mentions new objective facts in three ranges: repair costs, residual value, and total cost of ownership (TCO). The authors suggest a few pointers for future research.

Abdel-Wahab and Vogl (2011) studied the growth of productivity of the construction industry between Europe, US, Japan. The study was conducted using the EU LLEMS database. The authors concluded that productivity is one of the key drivers of financial development in the country's GDP. The trend analysis concluded that the total factor productivity of the nations is in decline for the period 1990-2005 except for the UK.

In a report distributed in June 2012, the Business Council of Australia (BCA) detailed that it costs extensively more to fabricate a variety of types of infrastructure in Australia than it does in the US. Air terminals ( $90 \%$ extra cost) and doctor's facilities ( $62 \%$ extra cost) were cited as the most pessimistic scenarios with different undertakings running from 26 to $43 \%$ extra cost. They utilized these figures to infer that Australia is a high cost, low-productivity condition for building infrastructure project. These cases depended on cost $/ \mathrm{m}^{2}$ figures distributed by a noteworthy worldwide construction consultancy (Best, 2012).

Watkins et al. (2009) classified factors affecting productivity into internal and external factors. Internal factors were termed for those factors which are beyond the control of management and External factors for those factors which arise or originate in and around the workplace. Doloi (2008) has studied the impact of poor productivity of construction workers on the cost and delay of the projects. And the findings suggest that cost and timely completion of any Project is significantly dependent on the workforce productivity. Analytical hierarchy process used to prioritise the factors affecting workforce construction productivity and the finding suggests that major significant factors are planning and schedule related. A number of researcher's identified and analyzed the factors affecting $\mathrm{CP}$ in different scenario's and ranked them on the basis of their severity of impact and relative importance index values derived using different approaches such as: reliability importance index, some statistical tools, analytical hierarchal analysis, principal component analysis or factor analysis, SOM-based models, system dynamics based approaches, and other tools and techniques (Dai et al., 2009; Grau et al., 2009b; Jarkas, 2015; Jarkas et al., 2015; Ma and Liu, 2018; Oral and Oral, 2010; Rivas et al., 2011; Sweis et al., 2016; Thomas and Sudhakumar, 2013). Kisi et al. (2017) provide a framework for estimating the labor productivity frontier and applying this framework to a pilot study that tests the feasibility of this framework against a single-worker, labor-intensive, sequential construction task.

Mani et al. (2017) highlight the issues in the current benchmarking techniques in construction productivity and critically analyses and examine the loopholes present in the current practices. And proposed a framework for estimating the productivity frontier for the construction industry.

Gurmu and Aibinu (2017) identify the construction equipment management practices that have the potential to improve productivity in multi-storey building projects.

\section{Research Methodology}

The methodology adopted for the study is to identify the factors affecting construction productivity form the literature review (to be specific from the paper "Critical Analysis of Factors Affecting the on-site Productivity in Indian Construction Industry") and the factors have been analyzed and explained in detail in this paper. This paper is the extended version of the previous paper and the statistical test applied to the paper are: Correlation between the factors has been calculated and the factors have been analyzed, and the KMO's table has been prepared to check the applicability of factor analysis, and a regression model has been proposed on the basis of results generated using SPSS 23. 
Table 1 Attributes affecting on-site construction productivity (Dixit et al., 2018)

\begin{tabular}{|c|c|c|c|}
\hline Attributes / variables & References & Attributes / variables & References \\
\hline Increases in land-use regulation & (Giandrea et al., 2008) & $\begin{array}{l}\text { Project management, planning } \\
\text { and scheduling, top management } \\
\text { support, rework }\end{array}$ & $\begin{array}{l}\text { (Ganesan, 1984; Jarkas et } \\
\text { al., 2015; Wang et al., 2013) }\end{array}$ \\
\hline $\begin{array}{l}\text { Equipment, drawing, tools, } \\
\text { availability of material, } \\
\text { weather condition }\end{array}$ & $\begin{array}{l}\text { (Abdul Kadir et al., 2005; } \\
\text { Mahamid, 2013; Chalker and } \\
\text { Loosemore, 2016; } \\
\text { Ertürk et al., 2016) }\end{array}$ & $\begin{array}{l}\text { Coordination among all team } \\
\text { members, leadership, top } \\
\text { management support, the flow of } \\
\text { funds, budget update, coordination }\end{array}$ & $\begin{array}{l}\text { (Iyer and Jha, 2005; } \\
\text { Dixit et al., 2017c; }\end{array}$ \\
\hline $\begin{array}{l}\text { Labor management, rework, } \\
\text { material, confined working } \\
\text { space, tools }\end{array}$ & $\begin{array}{c}\text { (Jarkas et al., 2012; Mojahed and } \\
\text { Aghazadeh, 2008) }\end{array}$ & $\begin{array}{l}\text { and communication, timely } \\
\text { feedback, and owner's competence } \\
\text { and favourable climatic condition. }\end{array}$ & Gesling et al 2007. Mo \\
\hline $\begin{array}{l}\text { Delays in inspection, decision } \\
\text { making, material, rework, tools } \\
\text { and equipment }\end{array}$ & $\begin{array}{c}\text { (Durdyev and Ismail, 2016; } \\
\text { Mojahed and Aghazadeh, 2008; } \\
\text { Olomolaiye et al., 1987) }\end{array}$ & $\begin{array}{l}\text { Rework, Poor supervisor } \\
\text { competency and } \\
\text { Incomplete drawings }\end{array}$ & $\begin{array}{l}\text { and Aghazadeh, 2008; Tam et } \\
\text { al., 2007; Jarkas et al., 2012; 2015; } \\
\text { Jarkas and Bitar, 2012; El-Gohary } \\
\text { et al., 2017) }\end{array}$ \\
\hline $\begin{array}{l}\text { Absenteeism, Rework and lack } \\
\text { of material }\end{array}$ & $\begin{array}{l}\text { (Jarkas and Horner, 2015; } \\
\text { Kaming et al., 1997; Watkins } \\
\text { et al., 2009; Rivas et al., 2011; } \\
\text { Zakeri et al., 1996; Jarkas, 2015; } \\
\text { Dai et al., 2009; Sao et al., 2017) }\end{array}$ & $\begin{array}{l}\text { Decision making, planning and } \\
\text { logistics, supply chain management, } \\
\text { labor availability, budget and } \\
\text { cash flow management, improper } \\
\text { construction method, frequent }\end{array}$ & $\begin{array}{l}\text { (Hiyassat et al., 2016; Kisi } \\
\text { et al., 2017; Moselhi and } \\
\text { Khan, 2012; Mahmood et }\end{array}$ \\
\hline $\begin{array}{l}\text { Shop drawings, equipment's, } \\
\text { motivation and support, } \\
\text { scheduling, material }\end{array}$ & $\begin{array}{c}\text { (Halligan et al., 1994; } \\
\text { Doloi, 2008; Jarkas et al., 2012; } \\
\text { Loosemore, 2014; Moselhi and } \\
\text { Khan, 2012; Pandey et al., 2017) }\end{array}$ & $\begin{array}{l}\text { changes in design, supervision } \\
\text { delay, the sequence of activities, } \\
\text { overcrowding a job location and } \\
\text { scope of activities. }\end{array}$ & al., 2014; Dixit et al., 2017a) \\
\hline $\begin{array}{l}\text { Revision in drawings, delays } \\
\text { in inspection, competency of } \\
\text { supervisor, martial availability }\end{array}$ & $\begin{array}{l}\text { (Mojahed and Aghazadeh, 2008; } \\
\text { Kaming et al., 1997; Zakeri et } \\
\text { al., 1996; Jarkas, 2015; Jarkas and } \\
\text { Bitar, 2012; Dixit et al., 2017b) }\end{array}$ & $\begin{array}{l}\text { Availability of material, the } \\
\text { experience of labor, skill set and } \\
\text { training, communication, the } \\
\text { financial position of the client }\end{array}$ & $\begin{array}{l}\text { (Loosemore, 2014; } \\
\text { Mahamid, 2013; Moselhi and } \\
\text { Khan, 2012) }\end{array}$ \\
\hline
\end{tabular}

Table 2 Findings of previous studies - attributes affecting construction productivity (Dixit et al., 2018)

\begin{tabular}{|c|c|c|c|c|c|}
\hline \multirow{2}{*}{$\begin{array}{l}\text { References } \\
\text { (Dai et al., 2009; Thomas and } \\
\text { Sudhakumar, 2013) }\end{array}$} & \multicolumn{5}{|c|}{ Findings (ranking of the attributes) } \\
\hline & $\begin{array}{l}\text { Availability of } \\
\text { material }\end{array}$ & $\begin{array}{c}\text { Drawing } \\
\text { management }\end{array}$ & Coordination & $\begin{array}{c}\text { Construction } \\
\text { equipment }\end{array}$ & $\begin{array}{c}\text { Cools and } \\
\text { consumables }\end{array}$ \\
\hline (Rivas et al., 2011) & Rework & Truck availability & Materials & Equipment & Tools \\
\hline $\begin{array}{l}\text { (Jarkas and Horner, 2015; Hiyassat et } \\
\text { al., 2016) }\end{array}$ & Management & Technology & Labor availability & Climate & $\begin{array}{c}\text { Education and } \\
\text { experience }\end{array}$ \\
\hline \multicolumn{6}{|l|}{ (Mahamid, 2013) } \\
\hline (Jarkas, 2015) & Labor skills & Coordination & Supervision errors & Drawings & $\begin{array}{l}\text { Delay in response } \\
\text { to information }\end{array}$ \\
\hline (Moselhi and Khan, 2010) & Temperature & Height & & & \\
\hline (Grau et al., 2009a) & \multicolumn{5}{|c|}{$\begin{array}{c}\text { The findings of the study suggest that craft labor productivity shall be improved using material } \\
\text { tracking technologies. }\end{array}$} \\
\hline (Oral and Oral, 2010) & \multicolumn{5}{|c|}{$\begin{array}{l}\text { The authors proposed and validate a SOM-based model to analyze the relationship between crew } \\
\text { productivity and various factors. }\end{array}$} \\
\hline (Ma and Liu, 2018) & \multicolumn{5}{|c|}{$\begin{array}{l}\text { The authors identify and measure a four-component decomposition of the temporal changes in } \\
\text { construction labor productivity, including technology, technology-utilization efficiency, the capital-labor } \\
\text { ratio and production capacity. }\end{array}$} \\
\hline (Vereen et al., 2016) & \multirow{2}{*}{\multicolumn{5}{|c|}{$\begin{array}{l}\text { The findings of the study suggest a consistent decline in the productivity of output / labor / hour. } \\
\text { The findings of the study suggest that high sustainable productivity shall be achieved under good } \\
\text { management practices. }\end{array}$}} \\
\hline (Kisi et al., 2017) & & & & & \\
\hline
\end{tabular}

\subsection{Reliability Cronbach's alpha value}

Dependability analysis is required to check the consistency of the data, and Cronbach's alpha test was the best way to check the reliability of the data collected through the questionnaire (Singh, A. et al., 2018). The value of Cronbach's alpha for this study is 0.715 which is considered to be good (Table 3). 
Table 3 Reliability / Cronbach's alpha for the attributes

\begin{tabular}{lc}
\hline Reliability Cronbach's alpha for the attributes \\
\hline Attributes & Cronbach's alpha \\
All attributes selected for the study & 0.715 \\
Factor 1 & 0.69 \\
Factor 2 & 0.72 \\
Factor 3 & 0.713 \\
Factor 4 & 0.85 \\
Factor 5 & 0.78 \\
\hline
\end{tabular}

\subsection{Kaiser- Meyer-Olkin (KMO) test and Bartlett's trial of sphericity}

KMO test is used to check the ampleness of the data used before applying factor analysis (principal component analysis) i.e. to check the applicability of factor analysis to the collected data first KMO test is advised by a number of authors (Dixit et al., 2017c; Iyer and Jha, 2005). The estimation of KMO speaks to the proportion of the squared connection between factors to the squared incomplete relationship between factors. The value of KMO varies in the range of 0 to 1 . The value closer to 1 is considered more reliable and significant. For the current study, its value is 0.68 , which is to be considered good for the study (Abdul Kadir et al., 2005).

\section{Result and findings}

\subsection{Factor Analysis}

In the previous paper, the factor analysis was performed using SPSS 23 and the results of the study are in Table 4. In the extended paper, the mathematical validity of the factor analysis has been checked and a regression model has been proposed for the factors affecting construction productivity in the Indian construction industry, using the linear regression model.

\subsection{Validating factor analysis}

The validation of factor analysis has been checked using the correlation in-between the attributes grouped to factor. The results of the correlation analysis conclude that the attributes grouped under factors having a minimum value of 0.4 or above. If the attributes were grouped in a factor they should be significantly correlated (Singh, S. et al., 2018). The value of Pearson correlation has been tabulated in Tables 5-9. The Pearson correlation is calculated using SPSS 23.

\subsection{Regression analysis}

The factors affecting construction productivity evolving from factor analysis are further analyzed using linear multiple regression using SPSS 23 software. The linear
Table 4 Factor analysis (Dixit et al., 2018)

\begin{tabular}{|c|c|c|}
\hline Attribute / Factor & Factor loading & $\begin{array}{l}\% \text { age of } \\
\text { variance } \\
\text { explained }\end{array}$ \\
\hline Site management & & $15 \%$ \\
\hline Training & 0.53 & \\
\hline Availability of material & 0.84 & \\
\hline Working condition & 0.57 & \\
\hline Working hours & 0.65 & \\
\hline Competency management & & $11.5 \%$ \\
\hline Rework & 0.46 & \\
\hline Poor construction method & 0.55 & \\
\hline Job security & 0.59 & \\
\hline Commitment and coordination & & $10.30 \%$ \\
\hline Response to change order & 0.55 & \\
\hline Revision in drawings & 0.79 & \\
\hline Pep talk & 0.61 & \\
\hline $\begin{array}{l}\text { Periodic meetings with } \\
\text { management and site personals }\end{array}$ & 0.55 & \\
\hline Resource management & & $9.1 \%$ \\
\hline Storage area for material & 0.49 & \\
\hline Adequate crew and composition & 0.63 & \\
\hline Planning & & $7.1 \%$ \\
\hline Change in scope & 0.49 & \\
\hline Project management & 0.63 & \\
\hline Total variance explained & & $53.3 \%$ \\
\hline
\end{tabular}

Table 5 Site management

\begin{tabular}{lcccc}
\hline & R14 & R1 & R17 & R8 \\
\hline R14 & 1 & & & \\
R1 & 0.42 & 1 & & \\
R17 & 0.46 & 0.52 & 1 & \\
R8 & 0.5 & 0.51 & 0.432 & 1 \\
\hline
\end{tabular}

Table 6 Competency

\begin{tabular}{lccc}
\hline & R7 & R9 & R18 \\
\hline R7 & 1 & & \\
R9 & 0.413 & 1 & \\
R18 & 0.46 & 0.48 & 1 \\
\hline
\end{tabular}

Table 7 Commitment and coordination

\begin{tabular}{lcccc}
\hline & R3 & R15 & R16 & R12 \\
\hline R3 & 1 & & & \\
R15 & 0.39 & 1 & & \\
R16 & 0.469 & 0.47 & 1 & \\
R12 & 0.512 & 0.45 & 0.417 & 1 \\
\hline
\end{tabular}

Table 8 Resource management

\begin{tabular}{ccc}
\hline & R4 & R5 \\
\hline R4 & 1 & \\
R5 & 0.58 & 1 \\
\hline
\end{tabular}

Table 9 Planning

\begin{tabular}{ccc}
\hline & R2 & R6 \\
\hline R2 & 1 & \\
R6 & 0.542 & 1 \\
\hline
\end{tabular}


Table 10 Regression model

\begin{tabular}{lcccc}
\hline $\begin{array}{l}\text { Attribute } \\
\text { code }\end{array}$ & Attribute & Coefficient & $\begin{array}{c}\text { Std } \\
\text { error }\end{array}$ & Probability \\
\hline R2 & Intercept & -0.512 & 0.241 & 0.0036 \\
R15 & $\begin{array}{c}\text { Change in scope } \\
\text { Revision in } \\
\text { drawings }\end{array}$ & 0.284 & 0.59 & 0.0000 \\
R7 & Rework & 0.212 & 0.062 & 0.0015 \\
R14 & $\begin{array}{c}\text { Training } \\
\text { R3 }\end{array}$ & 0.157 & 0.047 & 0.0025 \\
\hline
\end{tabular}

multiple regression analysis provides a model that consists a set of independent variable and one dependent variable (the value has been taken in the questionnaire as the overall impact of attributes over construction productivity in Indian construction projects).

$Y=a+b 1 X 1+b 2 X 2+\ldots b m X m \pm e$.

Where $Y$ is the dependent variable, $a$ is the constant, $b 1$ to $b m$ are the estimated regression coefficients, $X 1$ to $X m$ are the independent variables, and $e$ is the error.

The values of regression model show that, change in scope (R2), revision in drawings (R15) (Iyer and Jha, 2005), and response to change orders (R3) having a maximum impact over the construction productivity. And rework (R7), and training (R14) having a moderate impact over construction productivity. While comparing these findings with the RII findings of the previous paper (Dixit et al., 2018), the top three attributes are planning and scheduling, availability of material, and storage area for material (logistics management). Comparing both the findings of the regression model and the RII shows a clear contrast between both the findings. Such contrast highlights the fact that perceived importance

\section{References}

Abdel-Wahab, M., Vogl, B. (2011) "Trends of productivity growth in the construction industry across Europe, US and Japan", Construction Management and Economics, 29(6), pp. 635-644. https://doi.org/10.1080/01446193.2011.573568

Abdul Kadir, M. R., Lee, W. P., Jaafar, M. S., Sapuan, S. M., Ali, A. A. A. (2005) "Factors affecting construction labour productivity for Malaysian residential projects", Structural Survey, 23(1), pp. $42-54$.

https://doi.org/10.1108/02630800510586907

Arashpour, M., Wakefield, R., Blismas, N., Lee, E. W. M. (2014) "Analysis of Disruptions Caused by Construction Field Rework on Productivity in Residential Projects", Journal of Construction Engineering and Management, 140(2), 04013053. https://doi.org/10.1061/(ASCE)CO.1943-7862.0000804

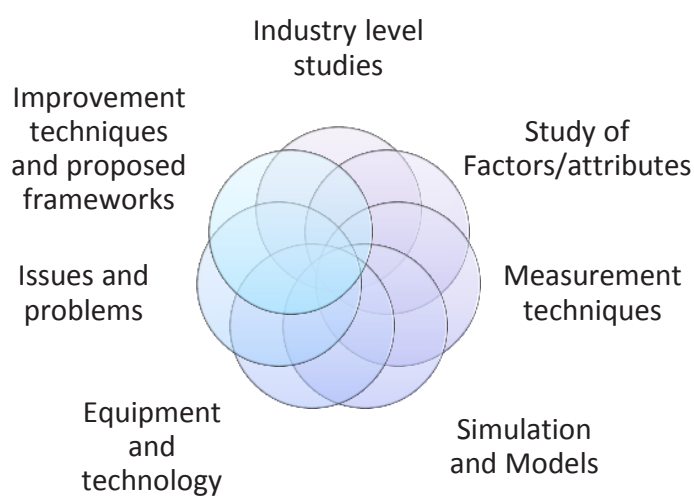

Fig. 1 Factors affecting construction productivity (Dixit et al., 2018)

as a single attribute and in terms of total impact may vary in terms of findings. These findings need to be analysed further in a more detailed and elaborative study.

\section{Conclusion}

The study aims to analyze the factors affecting the on-site productivity in construction project through descriptive statistics analysis. The study reveals that the factors identify in the previous papers has been validated and those shall be used to improve the on-site productivity of construction projects. The statistical tests performed in this study are reliability analysis, Pearson correlation analysis, and linear multiple regression analysis (Iyer-Raniga et al., 2010). The Findings of the study validate the previous finds and proposed a regression framework to improve the on-site construction productivity in the Indian construction industry. The results of the study shall benefit the industry to improve their productivity.

Best, R. (2010) "Using Purchasing Power Parity to Assess Construction Productivity", Australasian Journal of Construction Economics and Building, 10(4), pp. 1-10.

Best, R. (2012) "International Comparisons of Cost and Productivity in Construction: A Bad Example", Australasian Journal of Construction Economics and Building, 12(3), pp. 82-88.

Chalker, M., Loosemore, M. (2016) "Trust and productivity in Australian construction projects: a subcontractor perspective", Engineering, Construction and Architectural Management, 23(2), pp. 192-210.

https://doi.org/10.1108/ECAM-06-2015-0090

Dai, J., Goodrum, P. M., Maloney, W. F., Srinivasan, C. (2009) "Latent Structures of the Factors Affecting Construction Labor Productivity", Journal of Construction Engineering and Management, 135(5), pp. 397-406. https://doi.org/10.1061/(ASCE)0733-9364(2009)135:5(397) 
Dixit, S., Mandal, S. N., Sawhney, A., Singh, S. (2017a) "Area of linkage between lean construction and sustainability in Indian construction industry", International Journal of Civil Engineering and Technology, 8(8), pp. 623-636. [online] Available at: https://www. scopus.com/inward/record.uri?eid=2-s2.0-85028312536\&partner$\mathrm{ID}=40 \& \mathrm{md} 5=\mathrm{de} 36 \mathrm{c} 5 \mathrm{~d} 06517689354290494 \mathrm{ebf01074}$ [Accessed: 15th May 2018]

Dixit, S., Mandal, S. N., Sawhney, A., Singh, S. (2017b) "Relationship between skill development and productivity in construction sector: A literature review", International Journal of Civil Engineering and Technology, 8(8), pp. 649-665. [online] Available at: http://www. iaeme.com/MasterAdmin/UploadFolder/IJCIET_08_08_066/ IJCIET_08_08_066.pdf [Accessed: 15th May 2018]

Dixit, S., Mandal, S. N., Thanikal, J. V, Saurabh, K. (2018) "Critical Analysis of Factors Affecting the on-site Productivity in Indian Construction Industry", In: Creative Construction Conference 2018, Ljubljana, Slovenia, pp. 38-45.

https://doi.org/10.3311/CCC2018-006

Dixit, S., Pandey, A. K., Mandal, S. N., Bansal, S. (2017c) "A Study of Enabling Factors Affecting Construction Productivity: Indian Scnerio", International Journal of Civil Engineering and Technology, 8(6), pp. 741-758. [online] Available at: http://www. iaeme.com/MasterAdmin/UploadFolder/IJCIET_08_06_080/ IJCIET_08_06 080.pdf [Accessed: 15th May 2018]

Doloi, H. (2008) "Application of AHP in improving construction productivity from a management perspective", Construction Management and Economics, 26(8), pp. 841-854. https://doi.org/10.1080/01446190802244789

Dougherty, S., Chalaux, T., Herd, R. (2010) "What is holding back productivity growth in India?: Recent microevidence" OECD Journal: Economic Studies, 2009(1), pp. 1-22.

https://doi.org/10.1787/eco_studies-v2009-art3-en

Durdyev, S., Ismail, S. (2016) "On-site construction productivity in Malaysian infrastructure projects", Structural Survey, 34(4-5), pp. 446-462. https://doi.org/10.1108/SS-12-2015-0058

El-Gohary, K. M., Aziz, R. F., Abdel-Khalek, H. A. (2017) "Engineering Approach Using ANN to Improve and Predict Construction Labor Productivity under Different Influences", Journal of Construction Engineering and Management, 143(8), 04017045. https://doi.org/10.1061/(ASCE)CO.1943-7862.0001340

Ertürk, M., Tuerdi, M., Wujiabudula, A. (2016) "The Effects of Six Sigma Approach on Business Performance: A Study of White Goods (Home Appliances) Sector in Turkey", Procedia - Social and Behavioral Sciences, 229, pp. 444-452. https://doi.org/10.1016/j.sbspro.2016.07.154

Ganesan, S. (1984) "Construction Productivity", Habitat International, 8(3-4), pp. 29-42. https://doi.org/10.1016/0197-3975(84)90041-9

Giandrea, M. D., Cahill, K. E., Quinn, J. F. (2008) "Self-Employment Transitions among Older American Workers with Career Jobs", Bls working papers, U. S. Department of Labor, U. S. Bureau of Labor Statistics, Office of Productivity and Technology, Washington, USA, Working Paper 418. [pdf] Available at: https://www.bls.gov/ osmr/pdf/ec080040.pdf [Accessed: 15th May 2018]
Gosling, J., Naim, M., Fearne, A., Fowler, N. (2007) "Defining the lean and agile characteristics of engineer-to-order construction projects", In: CME 2007 Conference - Construction Management and Economics: "Past, Present and Future", Reading, United Kingdom, pp. 773-785. [online] Available at: http://www.scopus.com/inward/record.url?eid=2-s2.0-84877592573\&partnerID $=40 \& \mathrm{md} 5=526172 \mathrm{bddf7a} 94 \mathrm{f} 969 \mathrm{a} 5728473 \mathrm{db} 7 \mathrm{f} 03$ [Accessed: 15th May 2018]

Grau, D., Caldas, C. H., Haas, C. T., Goodrum, P. M., Gong, J. (2009a) "Assessing the impact of materials tracking technologies on construction craft productivity", Automation in Construction, 18(7), pp. 903-911.

https://doi.org/10.1016/j.autcon.2009.04.001

Grau, D., Caldas, C. H., Haas, C. T., Goodrum, P. M., Gong, J. (2009b) "Impact of fast automated tracking of construction components on labor productivity", In: $26^{\text {th }}$ International Symposium on Automation and Robotics in Construction, ISARC 2009, Austin, USA, pp. 505511. [online] Available at: http://www.scopus.com/inward/record. url?eid $=2$-s2.0-84863746030 \& partnerID $=40 \& \mathrm{md} 5=\mathrm{d} 393$ adlee $7 \mathrm{c}-$ c6e458652c5e5528cddd8 [Accessed: 15th May 2018]

Gurmu, A. T., Aibinu, A. A. (2017)"Construction Equipment Management Practices for Improving Labor Productivity in Multistory Building Construction Projects", Journal of Construction Engineering and Management, 143(10), 04017081.

https://doi.org/10.1061/(ASCE)CO.1943-7862.0001384

Halligan, D. W., Demsetz, L. A., Brown, J. D., Pace, C. B. (1994) "ActionResponse Model and Loss of Productivity in Construction", Journal of Construction Engineering and Management, 120(1), pp. 47-64. [online] Available at: https://ascelibrary.org/ doi/pdf/10.1061/\%28ASCE\%290733-9364\%281994\%29120 $\% 3 \mathrm{~A} 1 \% 2847 \% 29$ [Accessed: 15 th May 2018]

Hiyassat, M. A., Hiyari, M. A., Sweis, G. J. (2016) "Factors affecting construction labour productivity: a case study of Jordan", International Journal of Construction Management, 16(2), pp. 138-149. https://doi.org/10.1080/15623599.2016.1142266

Iyer-Raniga, U., Arcari, P., Wong, J. P. C. (2010) "Education for sustainability in the built environment: what are students telling us?", In: Proceedings $26^{\text {th }}$ Annual ARCOM Conference, Leeds, United Kingdom, pp. 1447-1456.

Iyer, K. C., Jha, K. N. (2005) "Factors affecting cost performance: Evidence from Indian construction projects", International Journal of Project Management, 23(4), pp. 283-295.

https://doi.org/10.1016/j.ijproman.2004.10.003

Jarkas, A. M. (2015) "Factors influencing labour productivity in Bahrain's construction industry", International Journal of Construction Management, 15(1), pp. 94-108. https://doi.org/10.1080/15623599.2015.1012143

Jarkas, A. M., Al Balushi, R. A., Raveendranath, P. K. (2015) "Determinants of construction labour productivity in Oman", International Journal of Construction Management, 15(4), pp. 332-344. https://doi.org/10.1080/15623599.2015.1094849

Jarkas, A. M., Bitar, C. G. (2012) "Factors Affecting Construction Labour Productivity in Kuwait", Journal of Construction Engineering and Management, 138(7), pp. 811-820. https://doi.org/10.1061/(ASCE)CO.1943-7862.0000501 
Jarkas, A. M., Horner, R. M. W. (2015) "Creating a baseline for labour productivity of reinforced concrete building construction in Kuwait", Construction Management and Economics, 33(8), pp. 625-639.

https://doi.org/10.1080/01446193.2015.1085651

Jarkas, A. M., Kadri, C. Y., Younes, J. H. (2012) "A Survey of Factors Influencing the Productivity of Construction Operatives in the State of Qatar", International Journal of Construction Management, 12(3), pp. 1-23.

https://doi.org/10.1080/15623599.2012.10773192

Kaming, P. F., Olomolaiye, P. O., Holt, G. D., Harris, F. C. (1997) "Factors influencing craftsmen's productivity in Indonesia", International Journal of Project Management, 15(1), pp. 21-30. https://doi.org/10.1016/S0263-7863(96)00019-1

Kannan, G. (2011) "Field Studies in Construction Equipment Economics and Productivity", Journal of Construction Engineering and Management, 137(10), pp. 823-828. https://doi.org/10.1061/(ASCE)CO.1943-7862.0000335

Kisi,K.P., Mani, N., Rojas, E. M., Foster, E. T.(2017)"OptimalProductivity in Labor-Intensive Construction Operations: Pilot Study", Journal of Construction Engineering and Management, 143(3), 04016107. https://doi.org/10.1061/(ASCE)CO.1943-7862.0001257

Li, Y., Liu, C. (2011) "Construction Capital Productivity Measurement Using Data Envelopment Analysis", International Journal of Construction Management, 11(1), pp. 49-61. https://doi.org/10.1080/15623599.2011.10773161

Loosemore, M. (2014) "Improving construction productivity: a subcontractor's perspective", Engineering, Construction and Architectural Management, 21(3), pp. 245-260. https://doi.org/10.1108/ECAM-05-2013-0043

Ma, L., Liu, C. (2018) "Decomposition of temporal changes in construction labour productivity", International Journal of Construction Management, 18(1), pp. 65-77. https://doi.org/10.1080/15623599.2016.1258755

Mahamid, I. (2013) "Contractors perspective toward factors affecting labor productivity in building construction", Engineering, Construction and Architectural Management, 20(5), pp. 446-460. https://doi.org/10.1108/ECAM-08-2011-0074

Mahmood, S., Ahmed, S. M., Panthi, K., Ishaque Kureshi, N. (2014) "Determining the cost of poor quality and its impact on productivity and profitability", Built Environment Project and Asset Management, 4(3), pp. 296-311. https://doi.org/10.1108/BEPAM-09-2013-0034

Mani, N., Kisi, K. P., Rojas, E. M., Foster, E. T. (2017) "Estimating Construction Labor Productivity Frontier: Pilot Study", Journal of Construction Engineering and Management, 143(10), 04017077. https://doi.org/10.1061/(ASCE)CO.1943-7862.0001390

Mojahed, S., Aghazadeh, F. (2008) "Major factors influencing productivity of water and wastewater treatment plant construction: Evidence from the deep south USA", International Journal of Project Management, 26(2), pp. 195-202.

https://doi.org/10.1016/j.ijproman.2007.06.003

Moselhi, O., Khan, Z. (2010) "Analysis of labour productivity of formwork operations in building construction", Construction Innovation, 10(3), pp. 286-303. https://doi.org/10.1108/14714171011060088
Moselhi, O., Khan, Z. (2012) "Significance ranking of parameters impacting construction labour productivity", Construction Innovation, 12(3), pp. 272-296. https://doi.org/10.1108/14714171211244541

OECD (2012) "India, Sustaining High Road and Inclusive Growth", OECD "Better Policies" Series, (October).

Olomolaiye, P. O., Wahab, K. A., Price, A. D. F. (1987) "Problems influencing craftsmen's productivity in Nigeria", Building and Environment, 22(4), pp. 317-323. https://oi.org/10.1016/0360-1323(87)90024-2

Oral, E. L., Oral, M. (2010) "Predicting construction crew productivity by using Self Organizing Maps", Automation in Construction, 19(6), pp. 791-797.

https://doi.org/10.1016/j.autcon.2010.05.001

Pandey, A. K., Dixit, S., Bansal, S., Saproo, S., Mandal, S. N. (2017) "Optimize the infrastructure design of hospital construction projects to manage hassle free services", International Journal of Civil Engineering and Technology, 8(10), pp. 87-98. [online] Available at: http://www.iaeme.com/MasterAdmin/ UploadFolder/IJCIET_08_10_011/IJCIET_08_10_011.pdf [Accessed: 15th May 2018]

Rivas, R. A., Borcherding, J. D., González, V., Alarcón, L. F. (2011) "Analysis of Factors Influencing Productivity Using Craftsmen Questionnaires: Case Study in a Chilean Construction Company", Journal of Construction Engineering and Management, 137(4), pp. 312-320. https://doi.org/10.1061/(ASCE)CO.1943-7862.0000274

Sao, A., Singh, S., Dixit, S., Pandey, A. K., Singh, S. (2017) "Quality, productivity and customer satisfaction in service operations: An empirical study", International Journal of Mechanical Engineering and Technology, 8(10), pp. 579-596. [online] Available at: http://www. iaeme.com/MasterAdmin/UploadFolder/IJMET_08_10_064/ IJMET_08_10_064.pdf [Accessed: 15th May 2018]

Sezer, A. A. (2015) "Contractor use of productivity and sustainability indicators for building refurbishment", Built Environment Project and Asset Management, 5(2), pp. 141-153.

https://doi.org/10.1108/BEPAM-11-2013-0065

Sezer, A. A., Bröchner, J. (2014) "The construction productivity debate and the measurement of service qualities", Construction Management and Economics, 32(6), pp. 565-574. https://doi.org/10.1080/01446193.2013.831464

Singh, A., Agarwal, P., Dixit, S., Singh, S., Sahai, S. (2018) "The Transition towards Sustainable Supply Chain Management: An Empirical Study", In: MATEC Web of Conferences, 172, 05001. https://doi.org/10.1051/matecconf/201817205001

Singh, S., Dixit, S., Varshney, D. (2018) "Sustainable construction management in education sector", International Journal of Engineering and Technology, 7(2), pp. 300-304. https://doi.org/10.14419/ijet.v7i2.9565

Sweis, G. J., Hiyassat, M., Al-Hroub, F. F. (2016) "Assessing lean conformance by first-grade contractors in the Jordanian construction industry", Construction Innovation, 16(4), pp. 446-459. https://doi.org/10.1108/CI-04-2015-0024

Tam, V. W. Y., Tam, C. M., Zeng, S. X., Ng, W. C. Y. (2007) "Towards Adoption of Prefabrication in Construction", Building and Environment, 42(10), pp. 3642-3654. https://doi.org/10.1016/j.buildenv.2006.10.003 
Thomas, A. V., Sudhakumar, J. (2013) "Critical Analysis of the Key Factors Affecting Construction Labour Productivity - An Indian Perspective", International Journal of Construction Management, 13(4), pp. 103-125.

https://doi.org/10.1080/15623599.2013.10878231

Sveikauskas, L., Rowe, S., Mildenberger, J., Price, J., Young, A. (2014) "Productivity Growth in Construction", Bls working papers, U. S. Department of Labor, U. S. Bureau of Labor Statistics, Office of Productivity and Technology, Washington, USA, Working Paper 478, [pdf] Available at: https://www.bls.gov/osmr/pdf/ ec140090.pdf [Accessed: 15th May 2018]

Vereen, S. C., Rasdorf, W., Hummer, J. E. (2016) "Development and Comparative Analysis of Construction Industry Labor Productivity Metrics", Journal of Construction Engineering and Management, 142(7), pp. 1-9.

https://doi.org/10.1061/(ASCE)CO.1943-7862.0001112

Wang, X., Chen, Y., Liu, B., Shen, Y., Sun, H. (2013) "A total factor productivity measure for the construction industry and analysis of its spatial difference: A case study in China", Construction Management and Economics, 31(10), pp. 1059-1071.

https://doi.org/10.1080/01446193.2013.826371
Watkins, M., Mukherjee, A., Onder, N., Mattila, K. (2009) "Using AgentBased Modeling to Study Construction Labor Productivity as an Emergent Property of Individual and Crew Interactions", Journal of ConstructionEngineering and Management, 135(7), pp. 657-668.

Zakeri, M., Olomolaiye, P. O., Holt, G. D., Harris, F. C. (1996) "A survey of constraints on Iranian construction operatives' productivity", Construction Management and Economics, 14(5), pp. 417-426. https://doi.org/10.1080/014461996373287

Zhai, D., Goodrum, P. M., Haas, C. T., Caldas, C. H. (2009) "Relationship between Automation and Integration of Construction Information Systems and Labor Productivity", Journal of Construction Engineering and Management, 135(8), pp. 746-753. https://doi.org/10.1061/(ASCE)CO.1943-7862.0000024 